\title{
Evaluating the Effect of Different Storage Conditions on Quality of Green Chillies (Capsicum annuum L.)
}

\author{
R. Hameed*, A.U. Malik, A.S.Khan, M. Imran \\ M. Umar and R. Riaz \\ Postharvest Research and Training Centre \\ Institute of Horticultural Sciences \\ University of Agriculture Faisalabad, 38040 \\ Pakistan
}

\begin{abstract}
Green Chilli (Capsicum annuum L.) is one of the most important vegetable crops in the world. Due to the perishable nature, it is liable to fast quality changes and spoilage (through wilting, shriveling, pathogenic disorders, water loss, etc.) after harvest under improper post-harvest management. The objective of the present study was to investigate the effect of different storage conditions viz., $\mathrm{O}^{\circ} \mathrm{C}(\mathrm{R} . \mathrm{H} 80-90 \%), 5{ }^{\circ} \mathrm{C}$ (R.H. 80$90 \%), 10{ }^{\circ} \mathrm{C}$ (R.H. 80-90\%) and $15{ }^{\circ} \mathrm{C}($ R.H 85-95\%) on the shelf life and quality attributes of green chillies. Each of the cold and humid storage conditions were applied to chilli for three weeks. After removal from storage, chillies were divided into two lots where one lot was kept at $15{ }^{\circ} \mathrm{C}(\mathrm{R} . \mathrm{H} .85-95 \%)$ and other at ambient conditions $\left(22{ }^{\circ} \mathrm{C} \pm 1{ }^{\circ} \mathrm{C}\right)$ with a R.H 65-70\% for one week shelf study. Changes in quality, weight, respiration, decay, softness, total chlorophyll content, marketability, acidity, and ascorbic acid content were recorded. After the three week storage, the fruits subjected to $10{ }^{\circ} \mathrm{C}$ exhibited a comparatively less weight loss, decay, softness, ethylene production and respiration rate but more firmness, compared to all other storage conditions. Retention of chlorophyll was higher at the lower temperatures $\left(0^{\circ} \mathrm{C}\right)$, However, chilling injury was observed on the fruit stored at $5{ }^{\circ} \mathrm{C}$ and $0{ }^{\circ} \mathrm{C}$, especially when taken out of storage and subjected to shelf life studies, where the fruits were found to be unmarketable after two days. The minimal quality loss occurred at shelf temperature of $15^{\circ} \mathrm{C}$ compared to the ambient temperature.
\end{abstract}

Keywords: Green chilies, quality, storage conditions

\section{INTRODUCTION}

Chilies are popular for their nutritional and medicinal values having a great demand in international trade. The demand for chilies is increasing day by day both in local and international markets. In the world, about 27.51 million tonnes of green chilies are produced annually over an area of 1857.86 thousand ha (FAO, 2010). In Pakistan, green chilies are cultivated on an area of 59.4 thousand ha with 121.9 thousand tonnes production (MINFAL, 2005-06). All over the world, higher yield with better quality and extended shelf life of fruits and vegetables have always been the major concern of researchers and stakeholders in order to get maximum returns. To facilitate access to domestic and export markets, fruits and vegetables storage potential and quality needs to be improved (Simmons et al., 1997). Like 
all other fresh fruits and vegetables, the potential market of green chilies is also directly correlated with the quality of the fruit. Postharvest handling of peppers and chilies are as crucial as the growing of the crop. Whether the pepper and chilies is used as fresh commodity or processed, appropriate postharvest handling is essential for a quality product. For marketing of green chilies, quality maintenance is necessary through all phases from field production to consumption (Bosland and Votava, 2000).

Green chilies are highly susceptible to water loss, sunscald and heat damage. Fresh green chilies losses water very quickly after harvest and begin to wrinkle and change colour within a few days without refrigerated storage. Darkening, shriveling or rotting of stem indicates that green chilies were not harvested recently (Bosland and Votava, 2000). The most encountered postharvest problems for green chilies are strong physiological activities, shriveling, wilting and fungal diseases. Moreover, these are sensitive to chilling injury if they are stored at or below $7{ }^{\circ} \mathrm{C}$. Cold storage permits fruit and vegetables to be offered for consumption or for processing in fresh condition over a long period. For postharvest handling of chilies and peppers, higher temperature is recommended while on the other hand, as temperature is increased, the rate of water loss is also increased (Ozden and Bayindirli, 2002). Proper storage temperature selection is the most important factor for storage of chilies and peppers. Optimum storage temperature range for chilies is reported between $7{ }^{\circ} \mathrm{C}$ to 13 ${ }^{\circ} \mathrm{C}$ for 2-3 weeks (Rico et al., 2002). The primary objective of the present study was to investigate the effect of different storage temperature to preserve the postharvest quality of green chilies during the three week storage period.

\section{MATERIALS AND METHODS}

Green mature chilies ( $c v$.) were harvested from a commercial farm, Layyah (lattitude $30^{\circ} 58$ 'N; longitude $70^{\circ} 56^{\prime} \mathrm{E}$ ), and transported to Postharvest Research \& Training Centre, Institute of Horticultural Sciences, University of Agriculture, Faisalabad, Pakistan in a referigirated truck $\left(15{ }^{\circ} \mathrm{C}\right.$ temperature). Healthy, uniform chilies, apparently free from any defects were selected, weighed $2 \mathrm{~kg}$ in each replication (plastic trays) and kept at different storage temperatures; $0{ }^{\circ} \mathrm{C}, 5{ }^{\circ} \mathrm{C}, 10{ }^{\circ} \mathrm{C}$ and $15{ }^{\circ} \mathrm{C}$, keeping relative humidity (RH) within $80-95 \%$ for three weeks. Four boxes were removed from each treatment unit after three weeks. After removal from cold storeage, two boxes of chilies out of four were kept at $15{ }^{\circ} \mathrm{C}(\mathrm{RH}$ at 85 $90 \%)$ and remaining two at ambient conditions $\left(22 \pm 1{ }^{\circ} \mathrm{C}\right)$ with $\mathrm{RH}$ at $60-65 \%$ for one week shelf study. Quality assessment was done just after removal from cold storage and after shelf-life period of one week.

Data Collection: To measure respiration rate and ethylene production, $250 \mathrm{~g}$ fruit were randomly selected from each treatment and placed into sealed plastic jars for one hour. Respiration rate was determined by measuring $\mathrm{CO}_{2}$ production using $\mathrm{CO}_{2}$ analyzer (model VAISALA, MI 70, Finland) and was expressed as $\mathrm{mg} \mathrm{CO}_{2} \mathrm{~kg}^{-1} \mathrm{~h}^{-1}$. Weight loss was calculated as the difference between initial fruit weight (before storage) and final fruit weight (after storage) and was expressed as a percentage. Decayed fruit weight was taken with the help of digital balance and decayed fruit $\%$ was calculated by using the formula: (weight of decayed fruit/total fruit weight) x 100. Fruit firmness was tested manually with feel of fingure pressure by using arbitrary scale where. 1 = very firm, $2=$ slightly soft, $3=$ moderate soft, 4 = very soft (Hameed, et al., 2010). Fruit colour was taken as a percentage of red. Titratable acidity (TA) and ascorbic acid in the juice was determined by using the method as described by Khan et al. (2009). 
Experimental design and statistical analysis: The data were subjected to analysis of variance (ANOVA), employing the Completely Randomize Design (CRD) and the treatment differences were statistically at $5 \%$ probability level $(P \leq 0.05)$.

\section{RESULTS AND DISCUSSION}

Respiration rate: The data pertaining to $\mathrm{CO}_{2}$ production as influenced by treatments showed highly significant results at removal day and after shelf period. Results indicated that the storage temperatures $0{ }^{\circ} \mathrm{C}\left(1.67 \mathrm{mg} \mathrm{kg}^{-1} \mathrm{~h}^{-1}\right)$ and $10{ }^{\circ} \mathrm{C}\left(1.75 \mathrm{mg} \mathrm{kg}^{-1} \mathrm{~h}^{-1}\right)$ had minimum respiration rate at removal day. It may be due to fruits under low temperature, the respiration rate is slow and as temperature increases the rate of respiration is fasten because every $10{ }^{\circ} \mathrm{C}$ increase the rate of respiration is roughly doubled (Jobling, 2012). Meanwhile, after one week of shelf-life the fruit stored at $10{ }^{\circ} \mathrm{C}$ slowed the lowest rate of respiration $\left(2.61 \mathrm{mg} \mathrm{kg}^{-1}\right.$ $\mathrm{h}^{-1}$ ) while the $0{ }^{\circ} \mathrm{C}$ storage exhibited the maximum rate $\left(6.28 \mathrm{mg} \mathrm{kg}^{-1} \mathrm{~h}^{-1}\right)$, significantly differing from all other storage temperatures (Fig.1). This result is in accordance with the findings of Mercado et al. (1995) who found that respiration rates of peppers stored at $10{ }^{\circ} \mathrm{C}$ lowered over the storage period of 20 days. And also freshly harvested chili or other hot peppers should be stored at $10{ }^{\circ} \mathrm{C}$ with 80-90\% RH (Meir et al., 1995; Miller and Risse, 1986 and Wang, 1977)

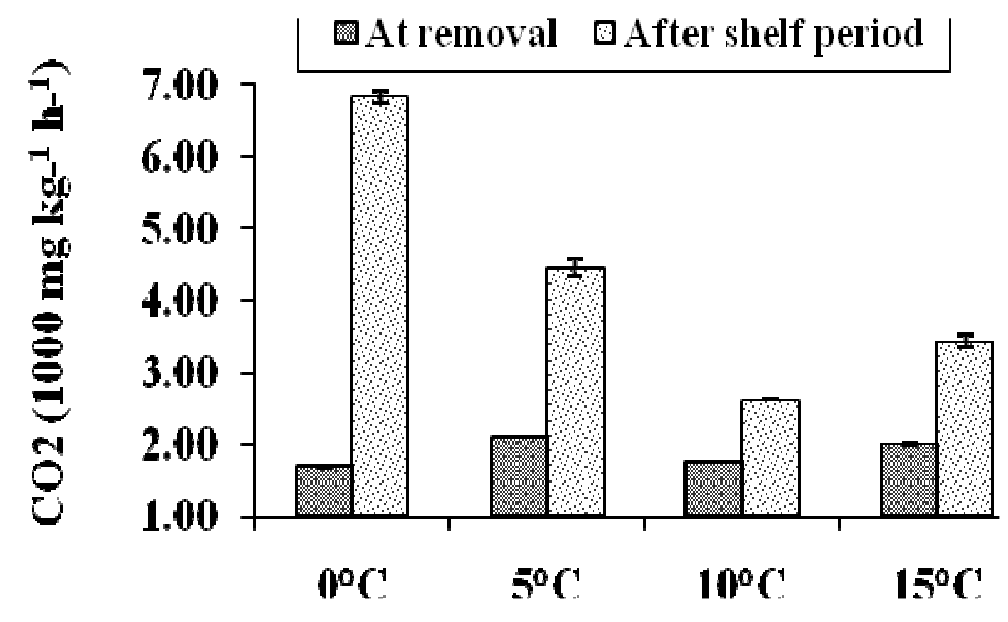

Fig.1. Effect of different cold storage temperatures on respiration rate of green chilies. (Vertical bar represents \pm SE).

Results for shelf temperatures remained significant, showing fruit kept at shelf temperature $15{ }^{\circ} \mathrm{C}$ had lower respiration rate $\left(3.93 \mathrm{mg} \mathrm{kg}^{-1} \mathrm{~h}^{-1}\right)$, compared to ambient condition $(4.73 \mathrm{mg}$ $\left.\mathrm{kg}^{-1} \mathrm{~h}^{-1}\right)$. However, the fruits which were under $10^{\circ} \mathrm{C}$ storage did not show a significant difference in respiration rate between ambient and low temperature $\left(15^{\circ} \mathrm{C}\right)$ maintained during shelf-life. 
Weight loss (\%): Analysis of variance for weight loss showed highly significant results for treatments at removal day and after shelf period. It was observed that minimum weight loss was at $10{ }^{\circ} \mathrm{C}(7.81 \%, 29.05 \%)$ and maximum weight loss was recorded at $15{ }^{\circ} \mathrm{C}(20.60 \%$, $41.61 \%$ ) at removal day and after shelf period (Fig. 2). It may be due to low respiratory activities at $10{ }^{\circ} \mathrm{C}$ storage temperature and as temperature increases rate of weight loss is also increased. These results are in agreement with the finding of Miller and Risse (1986) who reported that like sweet peppers, freshly harvested chili or other hot peppers should be stored at $10{ }^{\circ} \mathrm{C}$ temperature with 80-90 \% R.H. Similar results were presented by Meir et al. (1995), Mercado et al. (1995) and Chae et al. (2008). Results are also in line with the reports of Gonza'lez-Aguilar (2009) and Rico et al. (2002) who reported that pepper cultivars should be stored at temperature range $7-13^{\circ} \mathrm{C}\left(45-55^{\circ} \mathrm{F}\right)$.

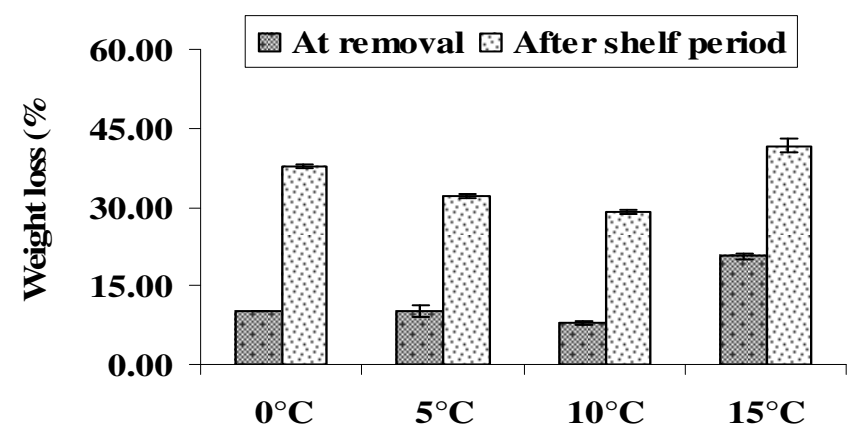

\section{Fig.2. Effect of different cold storage temperatures on weight loss (\%) of green chilies. (Vertical bar represents $\pm \mathrm{SE}$ )}

Results of the temperature during shelf-life was also highly significant, indicating significantly lower weight loss at $15^{\circ} \mathrm{C}(30.57 \%)$ compared to ambient conditions $(39.61 \%)$. However, the difference was minimum when storage temperature was at $10{ }^{\circ} \mathrm{C}$.

Decay (\%): No significant decay was observed for the fruits stored at $0{ }^{\circ} \mathrm{C}$ and $5{ }^{\circ} \mathrm{C}$ but found a slight decay at $10{ }^{\circ} \mathrm{C}(2.61 \%)$ and $15{ }^{\circ} \mathrm{C}(4.92 \%)$. After one week of shelf-life, the fruits stored at $10{ }^{\circ} \mathrm{C}$ showed significantly minimum percentage decay $(8.91 \%)$, whereas storage temperature $0{ }^{\circ} \mathrm{C}$ exhibited maximum decay (54\%). On the other hand, $5{ }^{\circ} \mathrm{C}$ and 15 ${ }^{\circ} \mathrm{C}$ were statistically at par with each other $(32 \%)$. It may be due to strong physiological activities and ethylene production which cause chilling injury at low temperature $\left(0{ }^{\circ} \mathrm{C} \& 5\right.$ ${ }^{\circ} \mathrm{C}$ ). When chilies were taken out of the storage and subjected to shelf studies, fruit were found to be unmarketable. These results are in accordance with the study of McClloch (1962) who observed increased surface pitting of peppers stored at $0{ }^{\circ} \mathrm{C}$ after 9 days and after 16 days at $5{ }^{\circ} \mathrm{C}$ (Abdel-Maksoad et al., 1975). These results are also similar with the findings of Chae et al. (2008) who reported that Capsicum genus is susceptible to chilling injury (CI) at temperatures below $7{ }^{\circ} \mathrm{C}$ and less decay at $10{ }^{\circ} \mathrm{C}$. Gonza'lez-Aguilar (2009) and Rico et al. (2002) reported a good storage temperature range 7 to $13{ }^{\circ} \mathrm{C}$ for peppers. Cabrera et al. (1992) also observed chilling injury of cucumber at below $10{ }^{\circ} \mathrm{C}$ while storage at $15{ }^{\circ} \mathrm{C}$ resulted in quality loss.

During shelf-life, $15{ }^{\circ} \mathrm{C}$ gave positive effect on decay (28.15\%) compared with ambient condition (35.23\% decay) agreeing with the report of Raffo et al. (2008). It was also 
observed that storage temperature $10{ }^{\circ} \mathrm{C}$ had minimum decay and $0{ }^{\circ} \mathrm{C}$ had maximum decay due to chilling injury at both shelf temperarures $15{ }^{\circ} \mathrm{C}$ and ambient condition (Table.1)

Table.1. Mean values of decay percent of green chilies for different cold storage temperatures and shelf temperatures after one week of shelf period

\begin{tabular}{cccc}
\hline & \multicolumn{3}{c}{ Decay (\%) } \\
\hline \multirow{3}{*}{ Storage temp } & \multicolumn{2}{c}{ Shelf temp } & \multirow{2}{*}{ Mean } \\
\cline { 2 - 3 } & $\begin{array}{c}\text { Ambient } \\
\left(22 \pm 1^{\circ} \mathrm{C}\right)\end{array}$ & \\
$0^{\circ} \mathrm{C}$ & $59.26^{\mathrm{a}}$ & $48.75^{\mathrm{b}} \mathrm{C}$ & $54.00^{\mathrm{a}}$ \\
$5{ }^{\circ} \mathrm{C}$ & $37.77^{\mathrm{c}}$ & $26.50^{\mathrm{f}}$ & $32.13^{\mathrm{b}}$ \\
$10^{\circ} \mathrm{C}$ & $10.63^{\mathrm{g}}$ & $7.19^{\mathrm{h}}$ & $8.91^{\mathrm{c}}$ \\
$15^{\circ} \mathrm{C}$ & $33.27^{\mathrm{d}}$ & $30.18^{\mathrm{e}}$ & $31.72^{\mathrm{b}}$ \\
Mean & $35.23^{\mathrm{a}}$ & $28.15^{\mathrm{b}}$ & \\
\hline
\end{tabular}

Firmness and colour retention: The fruits stored at $0-10{ }^{\circ} \mathrm{C}$ were more firm. than fruits stored at $15{ }^{\circ} \mathrm{C}$ at removal day while after one week of shelf period, storage temperature 10 ${ }^{\circ} \mathrm{C}$ exhibited significantly more firm fruits (1.75), compared with $15^{\circ} \mathrm{C}$ storage (2.37) which were statistically at par with $0{ }^{\circ} \mathrm{C}(2.27)$ (Fig. 4). It may be due to lower metabolic activities at $10{ }^{\circ} \mathrm{C}$ which retained fruit quality (firmness) for a longer time. These results are in conformity with Chae et al. (2008) who indicated that fruit firmness was highest at $10{ }^{\circ} \mathrm{C}$ and slight decrease in fruit firmness was observed after 45 days of storage.

At removal day, significantly higher red colour development was observed at higher storage temperature $15{ }^{\circ} \mathrm{C}(6.4 \%)$ than rest of the treatments $\left(0-10{ }^{\circ} \mathrm{C}\right)$. It could be because the retention of chlorophyll was higher at lower temperatures. After one week of shelf period minimum red colour development was observed in fruits stored at $0{ }^{\circ} \mathrm{C}(3.34 \%)$, followed by $10{ }^{\circ} \mathrm{C}(7.42 \%), 5{ }^{\circ} \mathrm{C}(11.50 \%)$ and $15{ }^{\circ} \mathrm{C}(26.79 \%)$ (Fig. 4). These results are in agreement with findings of Mercado et al. (1995) who worked out that peppers stored at $15^{\circ} \mathrm{C}$ began to show color change after one week while no colour change was noticed at $5{ }^{\circ} \mathrm{C}$ over 20 days as compared to $10{ }^{\circ} \mathrm{C}$.

As far as shelf temperature is concerned, minimum red colour $(7.54 \%)$ was observed in fruit subjected to a shel-flife of $15{ }^{\circ} \mathrm{C}$ as compared to ambient condition (16.99\%). Results are in context with the findings of Albanese et al. (2006) who reported that more chlorophyll retention in asparagus in cold storage as compared to ambient storage. Storage temperature of $0-5{ }^{\circ} \mathrm{C}$ were better in green colour retention (no red colour) compared to $10-15{ }^{\circ} \mathrm{C}$ (0.66 - $2.92 \%$ red colour) during one week shelf-life under both ambient and low temperature conditions. 

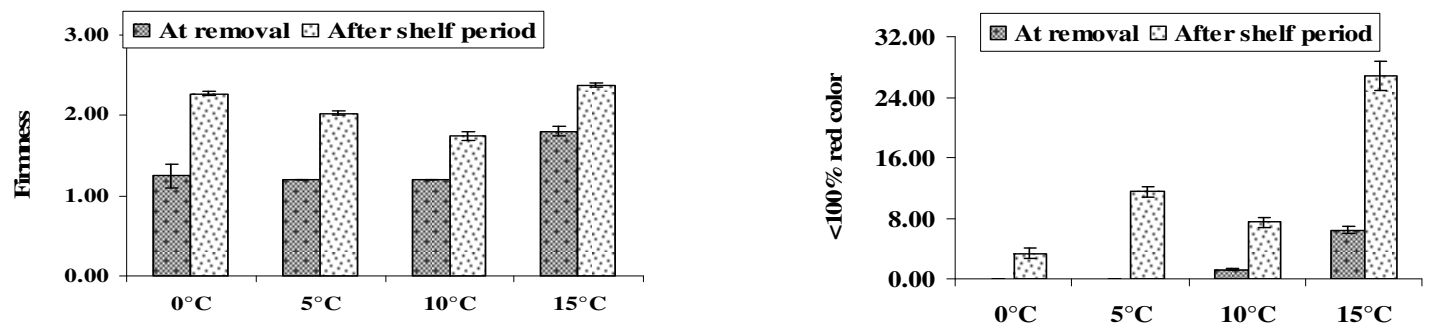

Fig.4. Effect of different cold storage temperatures on firmness (left) and red colour formation (right) of green chilies. (Vertical bar represents \pm SE).

Titratable acidity (TA) (\%) and ascorbic acid content: Maximum acidity was observed at $15{ }^{\circ} \mathrm{C}(0.49 \%)$ and was significantly higher After one week of shelf-life, the acidity did not further increase in low temperature storage $0-5^{\circ} \mathrm{C}$ but significantly increased in $5,10-15$ ${ }^{\circ} \mathrm{C}$ storage temperatures (Fig. 5). These results are in accordance with the study of Ramandeep and Geoffrey (2006) who found out slight increase in acidity of tomatoes at 15 and $25{ }^{\circ} \mathrm{C}$ during storage. Statistically highly significant results were obtained for the temperature during shelf-life. Higher acidity $(0.48 \%)$ was found at ambient condition as compared to $15{ }^{\circ} \mathrm{C}(0.41 \%)$. These results oppose the findings of Chourasia and Goswami (2001), who observed that loss of nutritive value would be minimized during cold storage as compared to ambient storage.
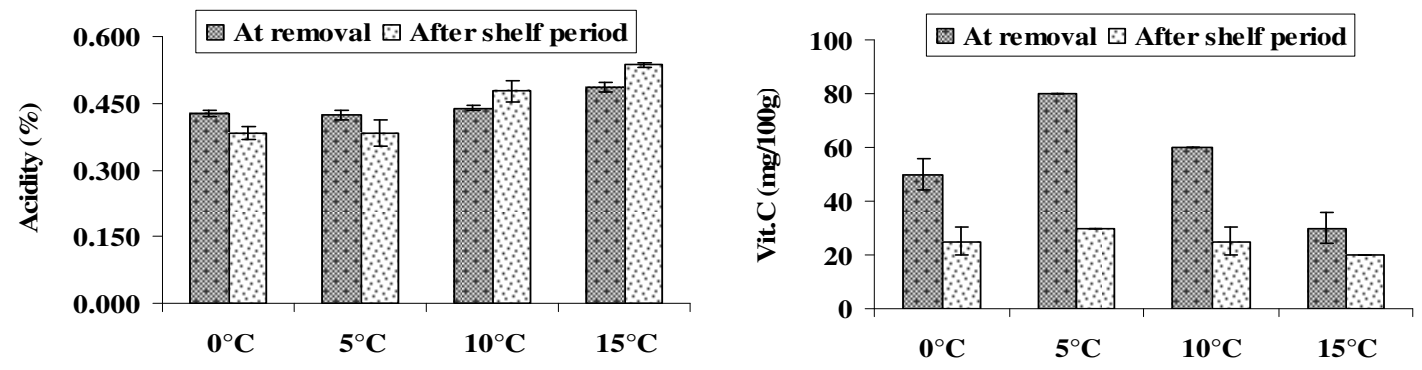

Figure.7. Effect of different cold storage temperatures on vitamin $\mathrm{C}(\mathrm{mg} / 100 \mathrm{ml})$ of green chilies (Vertical bar represents $\pm \mathrm{SE}$ ).

\section{CONCLUSIONS}

On the basis of the findings of this study, it can be concluded that $10{ }^{\circ} \mathrm{C}$ storage temperature performed better in slowing down the respiration rate, weight loss and decay, while maintaining the fruit firmness and overall quality. It was observed that retention of chlorophyll (green colour) was higher at lower storage temperatures, $0{ }^{\circ} \mathrm{C}, 5{ }^{\circ} \mathrm{C}$ and $10{ }^{\circ} \mathrm{C}$. 
After one week of shelf-life, minimum red color $(<100 \%$ red) development was achieved at storage temperature $0{ }^{\circ} \mathrm{C}$ followed by $10{ }^{\circ} \mathrm{C}, 5{ }^{\circ} \mathrm{C}$ and $15{ }^{\circ} \mathrm{C}$. Storage temperature $15{ }^{\circ} \mathrm{C}$ performed better in retention of acidity as compared to other storage temperatures. Results indicated that minimal quality loss occurred at shelf temperature $15^{\circ} \mathrm{C}$ compared to ambient. Low temperature (chilling) injury was observed on the fruits stored at $5{ }^{\circ} \mathrm{C}$ and $0{ }^{\circ} \mathrm{C}$, especially when taken out of storage and subjected to shelf-life studies. This study clearly pointed out that $10{ }^{\circ} \mathrm{C}$ as the best storage temperature for minimizing qualitative losses of green chillies during short-term storage.

\section{ACKNOWLEDGEMENT}

We gratefully acknowledge the financial support of Endowment Fund Secretariat and Punjab Agricultural Research Board (PARB), Lahore for operational expenses of the study and Postharvest Research \& Training Centre for their cooperation and provision of cold storage facility.

\section{LITRATURE CITED}

Abdel-Maksoad, M., Abou-Aziz, A.B., Abdel-Kader, A.S. and Abdel Samei,K.A. (1975). Effect of temperature on quality and decay percentage of 'California Wonder' pepper fruit grown in "Gharbia and Menofia" governatore during storage. Egypt. J. Hort. 2, 157-165.

Albanese, D. L. Russo, L. Cinquanta, A. Brasiello and M. Di Matteo. (2006). Physical and chemical changes in minimally processed green asparagus during cold-storage. Food Chem. 101(1), 274-280.

Bosland, P.W. and Votava, E.J. (2000). Peppers; vegetable and spice capsicum. crop production science in horticulture CAB international Publishing, Wallingford, UK. pp.145147.

Cabrera, R.M., M.E. Saltveit and K. Owens. (1992). Cucumber cultivars differ in their response to chilling temperatures. J. Amer. Soc. Hort. Sci. 117, 802-807

Chae S. L., M. K. Seong, L. C. Jeoung, M. L. Jong, B. S. Kim, G. A. Chul, O. J. Youl and H. J. Hae. (2008). Changes in fruit quality of paprika and color pimento (capsicum annuum 1.) stored at low temperatures. Acta Hort. 768, 539-544.

Chourasia, M.K. and T.K. Goswami. (2001). Losses of potatoes in cold storage vis-a-vis types, mechanism and influential factors. J. Food Sci. Tech. 38(4), 301-313.

Chourasia, M.K., R. Saha, A. De and P.K. Sahoo. (2004). Evaluation of storage losses in a commercial potato cold storage. J. Food Sci. Tech. 41(5), 507-510.

FAO. 2010. [Accessed on 10.01.10]. Available at www.fao.org/cs/css/top commodity.html.

González, M., A. Centurión, E. Sauri and L. Latournerie. (2009). Influence of refrigerated storage on the quality and shelf life of 'habanero' chili peppers (capsicum chinense jacq.). [Accessed on 12.05.12]. 
Avaiable at http://www.actahort.org/members/showpdf?booknrarnr=682_174.

Hameed R., A.U. Malik, M., Imran, A.S., Khan and S. Schouten. (2010). Effect of different controlled atmosphere storage conditions on shelf life and quality attributes of green chilies. Acta Hort. 786, 123-134

Jobling, J. (2012). Correct cool chain management is essential for all fruits and vegetables. Sydney Postharvest Laboratory Information Sheet.

Khan, A.S., Malik, A.U., Pervez, M.A., Saleem, B.A., Rajwana, I.A., Shaheen T., and Anwar, R. (2009). Foliar application of low-biuret urea and fruit canopy position in the tree influence the leaf nitrogen status and physico-chemical characteristics of Kinnow mandarin (Citrus reticulata Blanco). Pak. J. Bot. 4l(1), 73-85.

McClloch, L.P. (1962). Chilling injury and Aternaria rot of bell peppers. USDA Mkt. Res. Rep. No. 536,16.

Meir, S., Rosenberger, Y., Aharon, Z. Grinberg, S. and Fallik. E. (1995). Improvement of the postharvest keeping quality and color development of bell pepper (cv. 'Maor') by storage in CA at reduced temperature. Postharv. Biol. Technol. 5, 303-309.

Mercado, J.A., M.A. Quesada, M. Reids and M. Cantwell. (1995). Storage of bell peppers in controlled atmospheres at chilling and nonchilling temperatures. Acta Hort. 412, 134-142.

Miller, W.R. and L.A. Risse. (1986). Film wrapping to alleviate chilling injury of bell peppers during cold storage. Hort. Sci. 21, 467-468.

MINFAL. (2005-06). Economic Survey of Pakistan. Ministry of Food, Agriculture and Livestock (MINFAL), Federal Bureau of Statistics, Islamabad.

Ozden, C. and Bayindirli, L.J. (2002). Effects of combinational use of controlled atmosphere, cold storage and edible coating application on shelflife and quality attributes of green peppers. Eur. Food Res. Tech. 214, 320-326.

Raffo, A., I. Baiamonte and F. Paoletti. (2008). Changes in antioxidants and taste-related compounds content during cold storage of fresh-cut red sweet peppers. European Food Research Tech. 226(5), 1167-1174.

Ramandeep, M. and L.K. Geoffrey. (2006). Effect of different cold storage temperatures on tomatoes quality. Acta Hort. 223, 124-129.

Rico, D., A.B. Martin-Diana, J.M. Barat and C. Barry-R

yan. (2002). Extebtding and measuring the quality of fresh cut fruits and vegetables: A review. Trends in Food Sci. Technol. 18, 373-386. 
Simmons, S.L., P.J. Hofman, A.W. Whiley and S.E. Hetherington. (1997). Effects of preharvest calcium sprays and fertilizer, leaf: Fruit ratios and water stress on mango fruit quality. In: Coates, L.M., P.J.Hofman and G.I.Johnson (Ed.). (1998). Disease control and Storage Life Extension in Fruit. Proc.Int. workshop, Chiang Mai, Thialand., ACIAR Proceeding No. 81166, 19-26.

Wang, C.Y. (1977). Effect of $\mathrm{CO}_{2}$ treatment on storage and shelf-life of sweet peppers. J. Amer. Soc. Hort. Sci. 102, 808-812. 